\title{
Rawls in Portugal and Spain
}

\author{
João Cardoso Rosas University of Minho, Portugal
}

European fournal of Political Theory

(c) SAGE Publications Ltd, London, Thousand Oaks and New Delhi ISSN I $474-885$ I I(2) $243^{-2} 55 ; 02782$ I

AвSTRACT: First, this article puts forth a political and cultural explanation for the fact that the work of Rawls and other American liberal analytic political philosophers was neglected in Portugal during the I970s and I980s. Second, the article describes Portuguese reactions to Rawls's ideas in the I990s, focusing on commentaries by scholars and 'public intellectuals'. Throughout this period, there was a gradual shift from glib partisan judgements to more careful responses. Third, the reception of Rawls in Portugal is compared with the reception in Spain. This comparison shows that both broad social context and the nature of academia tended to be more hospitable to Rawls in Spain than in Portugal. However, the situation is changing.

Key words: American, analytic, justice, liberal, philosophy, political, Portugal, Rawls, reception, Spain

\section{Portugal: The Context of Reception}

When addressing the question of John Rawls's influence in Portugal, the first striking fact is the lack of influence for almost 20 years after the publication of A Theory of Fustice, in 1971. ${ }^{1}$ However, the absence of references to Rawls in the Portuguese philosophical and political literature of those years is not unique to Rawls as an individual. This quasi-invisibility of Rawls in Portugal epitomizes a long neglect in this country of the entire body of literature that Rawls helped to create and shape since the beginning of the I970s and that one may call 'American liberal analytic political philosophy'. Before beginning my account of the late reception of Rawls in Portugal, I will examine the causes of this extended neglect.

From 1933 until 1974 , Portugal was governed by a right-wing authoritarian regime known as the New State, under which basic rights and liberties were suppressed. The publication of books or any other printed works was tightly controlled by an office of censorship, and universities were under surveillance by the political police. During the New State period, several authors and university

Contact address: João Cardoso Rosas, Universidade do Minho, 4719 Braga, Portugal.

Email: rosas@ilch.uminho.pt 
professors were persecuted and jailed. Many others fled abroad. Teaching and publishing - particularly on political and social matters - was a luxury limited to people sympathetic to the regime. In this context, it was very difficult to come across public defences of liberal and democratic ideas.

Nevertheless, there was an organized and active opposition headed by the Portuguese Communist Party, a strictly Marxist-Leninist and pro-Soviet political organization. Although clandestine, the PCP attracted an important part of the intelligentsia opposed to the New State regime. By the end of the r96os, some communist intellectuals became even more radical, embracing varieties of Marxism such as Maoism.

The transition to democracy started on 25 April I974, with the Revolution of the Carnations. However, the Portuguese took two years to establish a new Constitution and a few more to reach democratic stability. The transition to democracy in the I970s was complicated by the fact that the Portuguese had to engage, simultaneously, in a process of granting independence to several colonies in Africa and Asia. Democratization coincided with decolonization.

In the summer of 1975, the radical forces of the Communist Party were winning the fight. The action of the PCP helped to hand over the former colonies to pro-Soviet liberation movements. Moreover, the communists were manœuvring to create a popular democracy in Portugal. The liberal democrats, headed by the leader of the Socialist Party, Mário Soares, engaged in a struggle against the communists and the far left, from which they would emerge as victors. The alternatives granted to the Portuguese people were 'pluralist democracy' (as it was then called) and communist-style 'popular democracy'. ${ }^{2}$ Most left-wing intellectuals preferred the latter to the former, but the majority of the population and some of their leaders thought differently.

In this highly polarized political and ideological struggle, political philosophers like Rawls and his American liberal colleagues did not address the choices that the Portuguese had to make. Most American authors did not provide a justification for the transition from authoritarian to democratic rule. Instead, they took for granted a liberal constitutional and political 'basic structure' that the Portuguese liberal democrats were still trying to establish in their own country, against the opposition of the Marxists. The alternative that the Portuguese faced in the I97os was not between egalitarian liberalism and libertarianism, Rawls versus Nozick. This kind of philosophical and political divide was a luxury that the Portuguese people could not afford in those years.

The 1980 s were a period of institutional stability and economic crisis, followed by recovery. After the normalization of democratic politics, the challenge that the country faced was economic, not political. 'Development' was the catchword of the day, replacing 'democratization' and 'decolonization'. In order to fulfil the promises of development or economic modernization, the main priority of the nation in this period was integration into the European Community. As a result 244 of this national strategy, Portugal became a full member of the European 
Community in 1986. In this respect, the political landscape was marked by a centrist consensus. Although both the extreme left and the extreme right expressed some reservations with regard to the European commitment of the country, the two main political parties - the Socialist Party (in fact, a social democratic party) and the Social-Democratic Party (a liberal-reformist party) - agreed on all the essentials of the 'European turn' of Portugal.

During the I980s, the intellectual controversies of American liberal analytic political philosophers continued to sound far removed from the concerns of the Portuguese. The Portuguese were thrilled by the prospect of a more comfortable life, together with the new highways, airports and malls. Most of these things started to materialize by the end of the decade. The per capita income of the country was rising and almost everybody seemed happy to pay the price of quick economic development.

At this time, the country was willing to accept the high costs of modernization, namely, the destruction of rural life in a traditionally peasant society, the unplanned growth of cities, the emerging phenomena of drug addiction and criminality in a country where these things were virtually non-existent. Such developments, however, did not stimulate a 'communitarian' response (Walzer or Sandel-style) to the 'individualist' (Dworkin or Rawls-style) outlook. This does not mean that the individualist versus communitarian controversy was not relevant at all in the political options of the country. Instead, what happened was that the Portuguese did not realize that such a controversy was, indeed, relevant. In the political climate of the 198 os there seemed to be no opting out of economic development and European integration, no matter at what cost.

In the I990s, the country finally realized that it had a place among other European nations. The prevailing ideology of those years was that Portugal was not an exceptional case in Europe anymore. Portugal was just a normal country, with sound democratic institutions and relative economic prosperity; it was a member of the $\mathrm{EC} / \mathrm{EU}$ and a respected state in the international arena. Moreover, it was a country with a glorious past and a privileged relationship with the former colonies in Africa and Brazil. In a word, the feeling of the country in the I990s was celebratory. The decade culminated with the Universal Exhibition of 1998 in Lisbon, in which the country celebrated this positive assessment of its own past and its optimism about the future. After a late and troubled transition to political and economic modernity, the people were proud of themselves, and they were proud of being Portuguese.

It is in the context of the I990s that American liberal analytic political philosophy became relevant in the eyes of some Portuguese intellectuals. This is partly because the country grew to see itself as a normal country, with the same kind of problems and alternatives to face as any other country in the modern world.

Moreover, the economic boom led to an important growth in the book industry. The Portuguese translation of $A$ Theory of fustice finally appeared in 1993, with an original preface by Rawls (written in 1990). ${ }^{3}$ In I997, only four years after 
its publication in English, Political Liberalism was also published in Portuguese. In 2000, the Portuguese version of The Law of Peoples appeared. However, the general state of translation in this field is still poor when compared with other European countries. Translation of commentaries on Rawls and American political philosophy include the little book by Chandran Kukathas and Philip Pettit, ${ }^{4}$ but not, for example, the overview of Contemporary Political Philosophy by Will Kymlicka, nor the book on Liberals and Communitarians by Mulhal and Swift. Michael Walzer's Spheres of Justice was translated in I999, but other fundamental books in the American debate - books by Robert Nozick, Michael Sandel, Charles Taylor, Ronald Dworkin, Bruce Ackerman - have yet to be translated.

The issues that alienated Portugal from Rawls's political philosophy during the I970s and the I980s were not merely related to the political agenda of the country. There were cultural reasons, as well. The educated elite - particularly in the fields of philosophy, law and the social sciences - were not fluent in English and they were not familiar with academic debates taking place in the Englishspeaking world. The foreign language of this elite was French and, in some cases, German.

In the field of general philosophy there was a widespread contempt for the analytical tradition prevalent in the English-speaking world. Instead, the phenomenological, hermeneutic and Hegelian/Marxist traditions were highly appreciated. Philosophers such as Edmund Husserl, Martin Heidegger, Jean-Paul Sartre, Maurice Merleau-Ponty, Emmanuel Levinas, Michel Foucault, Paul Ricoeur, Hans-Georg Gadamer and Jürgen Habermas were studied and taught. However, the Portuguese academia privileges the classics. Most doctoral theses are on authors such as Plato, Aristotle, Spinoza, Leibniz, Kant and Hegel. ${ }^{5}$

Moreover, political philosophy was barely existent in Portuguese academic institutions. There were no professional societies in this field, no specialized journals and no regular fora for researchers. Perhaps Portuguese scholars were afraid of engaging in this field because they did not want to be 'political, not metaphysical'. In other words, political and normative considerations in philosophy were - and still are - looked at with suspicion. The study of human action and norms was handed over to lawyers and social scientists, with their particular approaches.

Meanwhile, Rawls was translated into French by Catherine Audard. Théorie de la justice appeared in I987, a collection of selected essays entitled fustice et démocratie was published in I993 and Libéralisme politique appeared in I995. As a consequence of these translations, many Portuguese senior scholars gained access to the work of Rawls for the first time. Another important contribution came from Paul Ricoeur, one of the most respected philosophers in Portugal. In I99I, Ricoeur published Lectures I. Autour du Politique and, in I995, he published a book entitled Le fuste. The fact that Ricoeur dealt extensively with Rawls and other American philosophers made them more respectable in the Portuguese academia.

246 The Germans also helped. In I993, Jürgen Habermas - another philosopher 
who is highly respected in Portugal - published Faktizität und Geltung, which was translated into French as Droit et démocratie, in 1998. The exchange between Rawls and Habermas, originally published in the Fournal of Philosophy in I994, was also translated into French and published as a short book in 1997.

The relevance of German and, most of all, French references to Rawls and his critics did not lie only in their readability for the Portuguese. There was also a question of intellectual authority and fashion. Perhaps because both German and French philosophers presented Rawls as a central figure of contemporary thought, more scholars in Portugal felt inclined or even compelled to take his work into account in their own research. At this moment, younger scholars who were fluent in English were already reading and studying Rawls and other American liberal analytic political philosophers.

\section{The Reception of Rawls in Portugal}

Both the political and cultural reasons that delayed the joining of Portuguese scholars to the academic industry dealing with Rawls bear on the very first written manifestations of interest in Rawls's work. In a I990 issue - entitled 'Reason and Justice' - of the journal Filosofia, published by the Portuguese Philosophical Society, one can find two articles on the work of John Rawls. ${ }^{6}$ However, the fact that there were no translations at the time made it difficult for Portuguese philosophers to make any kind of probing examination of Rawls's ideas. The author of one of these articles actually admits that he is only exploring some topics from the Preface to $A$ Theory of Fustice. Moreover, there is a general tone of reservation in both articles, stemming from neo-Marxist standpoints. Let us consider some of these critical judgements.

According to Lopes Alves, the theory of Rawls is 'a true philosophical scandal'. Unlike modern social contract philosophers such as Hobbes, Locke and Rousseau, Rawls does not make explicit the political, economic, psychological and moral presuppositions of his conception of justice. Rawls supposes the liberal state, instead of justifying it. Moreover, Rawls conveys the idea that liberalism belongs to the 'nature of things'. A rational optimist, Rawls never raises the issues of individual and social irrationality analysed by authors such as Nietzsche, Freud, Marx and Heidegger. According to Lopes Alves - who quotes R. P. Wolff in a number of passages - Rawls's philosophy amounts to ideology, that is, a set of technical arguments that theorize but do not problematize the idea of justice in liberal advanced societies. That criticism aside, Lopes Alves praises Rawls for bringing Anglo-Saxon ethics back to the great tradition of western thought by virtue of opening the way to public ethics and to a re-evaluation of the principle of equality.

In another article, João Esteves da Silva criticizes Rawls for his lack of a theory of history. ${ }^{8}$ Such a theory - along the lines of Marx and Habermas - would make explicit the roots of Rawls's conception of justice in a particular social practice. 
According to Esteves da Silva, the principles of 'justice as fairness' reflect American society - they are not universal. Nevertheless, Rawls's endeavour also contains positive aspects. Rawls goes beyond the ideological field of economics by returning to the tradition of political economy. In Rawls's theory, economic relations are seen as relations between human beings and not as stones in the natural world. In this aspect, the critique of Esteves da Silva is perhaps less hostile to Rawls than the approach of Lopes Alves.

A similar - but not coincident - line of analysis is found in one of the two short articles published in 1994 in the journal Finisterra, which is a forum for intellectuals close to the Socialist Party and the so-called democratic left. Miguel Serras Pereira, who writes from the standpoint of 'radical democracy', also criticizes Rawls's theory of justice for the lack of a historical dimension. ${ }^{9}$ Quoting Ricoeur, Serras Pereira emphasizes the circularity of the argument of the original position. The principles of justice as fairness are a fiction of universality that is the result of a fictional choice-situation. As an alternative, Serras Pereira advocates the continuous construction of principles of justice without the veil of ignorance and under actual circumstances of deliberation. This is a requirement of radical democracy, he says, which aims at the participation of us all in the decisions that concern us all.

In a suggestive analysis that touches both on $A$ Theory of Fustice and Political Liberalism, José Lamego presents the political philosophy of Rawls as a form of 'Kantianism in a single country'. ${ }^{10}$ Analysing the evolution of Rawls's thought, Lamego talks about a 'contextualist turn' and even a form of 'moderate communitarianism' in Rawls's political liberalism, which reduces political philosophy to a hermeneutics of the present in Western liberal societies. Like Serras Pereira, Lamego stresses the importance of Rawls in contemporary philosophy, but he concludes that Rawls lost his democratic and reformist impulse in Political Liberalism. Whereas Theory is Kantian, enlightened and optimist, Liberalism takes on the Hegelian focus on institutions and stability. In this respect, Lamego adds, Rawls is a good interpreter of the Zeitgeist.

Political liberalism was also the main subject of analysis in an article published by António Manuel Martins in 1994, in the Revista Filosófica de Coimbra.${ }^{11}$ Martins analyses the communitarian critiques of Rawls and he presents the political liberalism of the latter as a response to these critiques. Martins also makes a detailed analysis of the idea of an overlapping consensus, as the centrepiece of Rawls's political liberalism. The same scholar pursued his reflection with an article on The Law of Peoples. ${ }^{12}$ In this article, Martins took on board the central ideas of Rawls's political liberalism and summarized the extension of the social contract idea to a 'Just Society of Peoples', focusing on the role of basic human rights.

In 1997, Alexandre Franco de Sá wrote on the problem of toleration in the political philosophy of John Rawls, in the journal Philosophica, published by the Department of Philosophy of the University of Lisbon. ${ }^{13}$ This article is a descriptive account of the political liberalism of Rawls seen as a theory on tolerance. 
In the same year of I997, João Rosas published an analysis and critique of Rawls's doctrine of political liberalism in the Revista Portuguesa de Filosofia.${ }^{14}$ The author of this article argued that Rawls was right about taking doctrinal pluralism seriously but that he did not draw from that move all the necessary conclusions. According to Rosas, once one takes doctrinal pluralism into account, one must also - and for the same reasons - take justice pluralism into account. As a consequence, Rosas concludes, Rawls's political liberalism is unable to provide reasonable hope in a consensus regarding the principles of basic justice. In another text, the same author deals with the idea of neutrality in Rawls. ${ }^{15}$ The approach in this piece is mostly analytic. It aims at situating the work of Rawls and other 'neutralist' philosophers vis-à-vis contemporary liberal perfectionists, such as Joseph Raz.

So far, I have mentioned commentaries by philosophers. However, philosophers do not have the monopoly of commentary on Rawls's ideas. One of the most creative uses of the work of Rawls in Portugal may be found among sociologists. In a book published in 1997, Manuel Vilaverde Cabral makes an attempt to give an empirical basis to the liberal egalitarianism of Rawls. ${ }^{16}$ His hypotheses are the following: (a) there is a correlation between political citizenship and social fairness, between the first and the second principle of the conception of 'justice as fairness'; (b) there is a correlation between political citizenship and social fairness, on the one hand, and economic development, on the other hand. This second correlation - between justice and economic growth - is particularly relevant for a country like Portugal. I have noted that development has come before justice in the Portuguese ideology since the I98os. By linking economic development with social fairness and political participation, Vilaverde Cabral is making an argument that aims at the reversal of this ideology. In Rawls's terms, one could say that Vilaverde Cabral wants to show that, at least in the case of Portugal, fair political rights, equality of opportunity and the improvement of the situation of the worstoff members of society is the best way to achieve economic efficiency.

By the mid-I99os, when the translation of $A$ Theory of fustice finally appeared and the written comments on the political philosophy of Rawls became more probing, Rawls started to be widely taught in universities at the undergraduate level. This was true in philosophy departments, but also in other social sciences departments and, in particular, in law schools.

Law schools are to be accounted for the leading role in the teaching of Rawls's work. This is particularly true of the University of Coimbra Law School. However, lawyers tend to present Rawls as part of a syncretic view of contemporary constitutional philosophy that also includes the work of Hart, Dworkin, Habermas and Luhmann (perhaps because of this peculiar approach to political philosophy, one cannot find any written comments on Rawls in law journals). Following the law schools, philosophy departments at major universities started to teach Rawls and other liberal philosophers. This was the case in the University of Lisbon, the New University of Lisbon, the University of Coimbra and the 
University of Minho. In a less systematic way, the same happened in departments of sociology and political science.

An important initiative that may account for generating interest in the work of Rawls, his friends and his critics was the course in political theory that took place every year in the Arrábida Summer University near Lisbon between 1993 and 1999. These courses were taught by Portuguese scholars, but also by Englishspeaking scholars such as Steven Lukes, John Gray, Raymond Plant, William Galston, John Tomasi, Steven Macedo, Chandran Kukathas.

The Portuguese scholar who used to organize the Summer Courses in Arrábida, João Carlos Espada, established in 1997 the Institute of Political Studies at the Portuguese Catholic University, in Lisbon. ${ }^{17}$ In the framework of this institute, a masters and $\mathrm{PhD}$ programme in Political Science and Theory was launched. This is a unique programme in the country, which focuses on AngloAmerican approaches in the field. In this programme, the work of Rawls and of other liberal philosophers is carefully studied. Besides regular seminars by Portuguese scholars, the programme also includes intensive seminars by American and other English-speaking visiting professors.

The work of Rawls has also been popularized in the press. One of the most enduring traditions in the Portuguese press is that of 'public intellectuals'. Portuguese public intellectuals are sometimes scholars, other times they are journalists, writers, politicians, etc. These public intellectuals write weekly chronicles - the most prolific of them write daily chronicles - in the major newspapers. Although several of them are learned people, their references to philosophers in the daily or weekly press is inevitably more political than academic. However, these references are extremely important because the agenda and the terms of public debate in Portugal are framed and constructed by public intellectuals, whatever the subject.

In the press, Rawls was first identified and praised as a left-wing liberal, a nonexistent entity in the Portuguese political landscape. However, he also has been identified as a liberal social democrat, which makes more sense to Portuguese ears. This is why Rawls is often praised by public intellectuals who are politically close to the Socialist Party. ${ }^{18}$ Other public intellectuals on the left tend to be dismissive about his work. They easily associate Rawls with market liberalism and they fail to value the strong egalitarian aspect of the conception of 'justice as fairness'. With some exceptions, this group of people still reproduces the kind of neo-Marxist and radical critique that was exemplified above.

The first aspect that non-Marxist left-wing intellectuals emphasize is the priority of justice over economic efficiency or utilitarian concerns. This point was one of the mantras of the Socialist Party when this party was in the opposition during most of the I990s. After coming to power in 1995, this party continued to use Rawls's ideas to refuse the 'economicist' perspective of those who claim that redistributive policies have been counterproductive for the Portuguese economic modernization. 
The second issue which leads public intellectuals to refer to the work of Rawls is social welfare. The reason for this was that the main social reform put in practice by the government of the Socialist Party was a 'Guaranteed Minimum Income' programme. Needless to say, there is no justification for a GMI programme in Rawls's theory of justice. This is not required since the 'difference principle' already aims at the amelioration of the situation of the worst-off members of society. However, a Rawlsian-like argument in favour of a GMI can be and has been put forth by authors such as Jeremy Waldron and, in a radical form, by Philippe van Parijs.

Public intellectuals on the traditional right tend to neglect the work of Rawls, rather than criticize it. The Portuguese right is reluctant openly to oppose the politics of social justice, since it is Catholic and close to the social teaching of the Church. Even before the right emerged as a democratic force, in I974, the New State regime, which also followed the teachings of the Church, could present itself as a third way, between neo-liberalism and socialism. With the democratic regime, the Portuguese right continued to refuse both 'statist' socialism and 'savage' liberalism. Pure marketers are difficult to find in Portugal. In this context, it comes as no surprise that, at least at the rhetorical level, the ambiguous principles of equality of opportunity and of improving the welfare of the least favoured members of society are generally defended by the traditional right. ${ }^{19}$

More recently, one can find among public intellectuals a liberal-conservative critique of Rawls. ${ }^{20}$ One aspect of this critique of Rawls focuses on the absence of considerations of merit in his principles of justice. This critique is in line with what William Galston - who is not a conservative, but a New Democrat - argued in Liberal Purposes. According to Galston, the moral irrelevance of merit in the justification of Rawls's principles severs the link between the American left and its constituency. In fact, the American people seem to put a lot of emphasis on personal effort and merit as a legitimate source of wealth. For some intellectuals, Portuguese society should embrace these non-Rawlsian values.

Another aspect of the liberal-conservative critique of Rawls deals with the priority of justice over the good, which is interpreted as leading to an aggressive defence of the neutrality of the state. This critique is very much in line with what Michael Sandel meant when he accused Rawls of defending a deontological liberalism that undermines the moral fabric of historical communities. According to Portuguese conservatives, examples of the wrong things that state neutrality produces are permissive attitudes towards practices that are intrinsically wrong, such as abortion, sexual education, drug abuse, homosexuality and so on and so forth.

Along the same lines, Francisco Sarsfield Cabral has repeatedly criticized Rawls for his defence of state neutrality and for his individualistic outlook. ${ }^{21}$ Although Cabral would reject the label 'conservative', he explicitly opposes Rawls's views for failing to understand the limitations of moral pluralism. For Cabral, the state cannot - and should not - 'privatize' all forms of religious and moral conviction. 
Otherwise, the pluralism that fortunately characterizes liberal societies will lead to relativism and moral indifference.

\section{A Comparison Between Portugal and Spain}

My analysis of the reception of Rawls's work in Spain will not be as exhaustive as my analysis of his reception in Portugal. Nevertheless, a brief comparison between the two countries may be of interest, as it sheds some light on the specificity of the Portuguese case. If my explanation for the delay in the reception of Rawls and other American liberal analytic political philosophers in Portugal is correct, one should perhaps find a similar situation in Spain, since the two countries are close in geography and history. However, this is not quite the case.

Spain had its own transition to democracy when the dictator Francisco Franco died and was replaced by Juan Carlos I, who became the King of Spain on 22 November 1975. Because there was no revolution in Spain, the transition was smoother than in Portugal. However, it was not easy. In February I98I, the far right attempted a military coup, which was aborted by the intervention of King Juan Carlos. After this episode, Spanish democratic institutions gained stability.

In contrast to Portugal, the Spanish road to economic development was initiated during the times of the dictatorship. Portugal remained isolated for a long time and started to open its economy very slowly in the I96os. Conversely, the government of Franco put into practice a vast programme of economic modernization in the I950s. When the two countries joined the European Community which they did on the same day - Spain was well ahead of Portugal in terms of economic development, notwithstanding huge asymmetries among its regions.

The economic development and euphoria that marked Portugal in the I99os took place in Spain in the I980s. This was the decade in which the Spanish people prepared the Olympic Games in Barcelona and the World Exhibition in Seville. Both events took place in 1992.

The cultural conditions in Spain were also more favourable than in Portugal to the reception of the work of Rawls and other American philosophers. Although these are neighbouring countries, the academic and cultural relations between them are barely existent. Whereas Spanish scholars tend to ignore their smaller neighbour, the Portuguese tend to think that it is better to deal with the centre (France and Germany in the past, the United States and other English-speaking countries in the future) rather than with another periphery.

Moreover, the nature of the Spanish academy was different from its Portuguese counterpart. Unlike the Portuguese, the Spanish were not francophone nor francophile. They did not have to wait for the reception of Rawls in France to engage in their own commentary of this author. Spanish academia was more open to external influences. The Spanish were perhaps influenced by Germany, but the Germans were quicker than the French in welcoming Rawls as a necessary reference for political philosophers, lawyers and social scientists. 
Last but not least, Spanish universities were less hostile to the analytic trend in general philosophy, not just in political philosophy - than the Portuguese. The interest of Spanish philosophers in analytical philosophy was quite widespread in the fields of epistemology and the philosophy of science. This contributed to create an environment open to a similar approach in political philosophy.

The Spanish translation of $A$ Theory of fustice, which appeared as early as I979, was controversial. ${ }^{22}$ Apparently, it is a deficient translation in terms of vocabulary and it raises confused interpretations. Moreover, it is odd in another aspect. A careful study conducted by Professor Maria Xosé Agra Romero from the University of Santiago de Compostela yielded the conclusion that this translation had been made directly from the version of $A$ Theory of fustice originally published in the United States. This was unlike all the other translations available in the international market - including the Portuguese one - which were made from a version revised by Rawls.

The problems with this translation, however, did not prevent the Spanish learned public from developing a growing interest in the work of Rawls and other American liberal analytic political philosophers. The publication of $A$ Theory of fustice in Spain was followed by the translation of other participants in the American debate, such as Dworkin and Wolff. Commentaries in Spanish language did not take a long time to appear, including an influential textbook by the Argentinian philosopher Carlos Nino.

According to Jesus Ignacio Martinez, I985 was the annus mirabilis for the commentaries of Rawls in Spain. ${ }^{23}$ This was the year in which most of the Rawls's scholars published their doctoral theses as books: Fernando Vallespín, Maria Xosé Agra, Jesus Ignacio Martinez and Maria Dolores González. ${ }^{24}$ Many other scholars published articles and essays dealing with Rawls in and around $1985 .{ }^{25}$

The Spanish translation of Political Liberalism appeared in 1996, whereas the translation of The Law of Peoples was published in $200 \mathrm{I}$. However, the reaction of Spanish scholars to the developments of Rawls's political philosophy since the mid-I980s preceded these translations. The body of literature on Rawls in Spain has never ceased to grow. ${ }^{26}$

The influence of Rawls in Spain is impressive when compared to Portugal. The fact that Spain is a larger country than Portugal does not explain everything. The economic and cultural aspects that I have pointed out above should also be taken into account as part of a more satisfactory explanation of the apparent popularity of Rawls in Spain, in contrast to his discrete presence in Portugal.

Besides broad contextual aspects, the difference between academic institutions in the two countries was decisive. The character of the Portuguese academia in the fields of philosophy, law and the social sciences made it less hospitable to the influence of American political philosophy in general and to the work of Rawls in particular. This lack of openness of the academic fora to this analytic and liberal political philosophy was a fatal hazard for the Portuguese. Because the entire field of political philosophy was energized in the last quarter of the 2 oth century by 
Rawls and his American colleagues, it comes as no surprise that the field remained weak in Portugal.

However, the tide is changing. The Law of Peoples appeared in Portugal before it appeared in Spain. A growing number of dissertations and publications about Rawls are in progress in Portuguese academia. As the late Robert Nozick famously put it back in 1974, 'Political philosophers now must either work within Rawls's theory or explain why not.. ${ }^{27}$ This is true still today and Portuguese philosophers are finally coming to grips with this fact. They must go on wrestling with Rawls's vision, in order to move beyond it.

\section{Appendix: A Brief Chronology of the Reception of Rawls in Portugal and Spain}

I979: Spanish edition of $A$ Theory of fustice

1985: Publication of several books on Rawls in Spain

I993: Portuguese edition of $A$ Theory of Fustice

1996: Spanish edition of Political Liberalism

I997: Portuguese edition of Political Liberalism

1997: Spread of commentary on Rawls in Portugal

2000: Portuguese edition of The Law of Peoples

2001: Spanish edition of The Law of Peoples

\section{Notes}

I. Actually, John Rawls's A Theory of fustice appeared only in I972, but the copyright is from i97I.

2. 'Pluralist democracy' was the label for what Americans and others call 'liberal democracy' and Germans call 'Rechtstaat'.

3. The content of this piece is close to the content of the famous Preface to the French edition of $A$ Theory of Justice, dated from I987, now in John Rawls (1999) Collected Papers, pp. 4I 5-20. Cambridge, MA: Harvard University Press.

4. Chandran Kukathas and Philip Pettit (1995) Fobn Rawls: Uma Teoria da Fustiça e os seus Críticos. Lisbon: Gradiva.

5. AAVV (1999) Perfil da Investigação Científica em Portugal: Filosofia. Lisbon. Observatório das Ciências e das Tecnologias.

6. Before this issue of Filosofia, the journal Critica published an issue on 'Philosophy and Politics', which included two translated pieces that mentioned the work of Rawls: an interview with Dworkin and an essay by Fernando Vallespin and Rafael del Aguilla. However, there are no contributions by Portuguese authors, with the exception of the editor's introduction. See Crítica 3 (1988).

7. João L. Alves (I990) 'A Noção de Contrato Social nos Modernos e em Rawls', Filosofia 4(I/2): 52-104.

8. João E. Da Silva (I990) 'Rawls e a Economia Política', Filosofia 4(I/2): I05-i6.

9. Miguel S. Pereira (I 994) 'À Margem da Edição Portuguesa de Uma Teoria da fustiça de John Rawls', Finisterra I 5: I 55-6o.

ıo. See José Lamego (I994) 'Kantismo "Fin-de-Siècle", Finisterra I 5: I6I-8. 
I I. António M. Martins (I 994) 'Liberalismo Político e Consenso Constitucional', Revista Filosófica de Coimbra 3: 32 I-59.

I 2. António M. Martins (2000) 'Liberalismo Político e Direitos Humanos', Arquipélago (Filosofia) 7: 33-56.

I3. Alexandre F. de Sá (r 997) 'O Problema da Tolerância na Filosofia Política de John Rawls', Philosophica 10: 107-20.

I4. João C. Rosas (I997) 'Justiça e Pluralismo: O Novo Desafío de Rawls', Revista Portuguesa de Filosofia 53: 55 I-65.

I 5. João C. Rosas (I997) 'Deverá o Estado liberal ser neutro?', in João Carlos Espada (ed.) Liberdade, Virtude e Interesse Próprio, pp. 69-9o. Lisbon: Europa-América.

I6. Manuel V. Cabral (1997) Cidadania Política e Equidade Social em Portugal. Lisbon: Celta.

I7. See http://www.ucp.pt/iep/iep.htm

I8. This was the case with the column by Guilherme de Oliveira Martins in the daily newspaper Diário de Notícias, and of the column by Manuel Maria Carrilho in Público, another daily paper.

I9. This rhetoric, however, did not prevent ferocious attacks against the Guaranteed Minimum Income programme by right-wing intellectuals and political leaders.

20. See the column by João Carlos Espada in the daily newspaper Público and in the weekly newspaper Expresso. For the critique of liberal neutrality, see also João C. Espada (I998) A Tradição da Liberdade, $\$ 37$. Cascais: Princípia.

2 I. Most of the pieces on Rawls published in newspapers by this Catholic journalist - close to the Social-Democratic Party - can now be found in Francisco S. Cabral (200I) Ética na Sociedade Plural. Coimbra: Tenacitas.

22. On this polemic, see Maria X. Agra (1983) 'Es la versión castellana de $A$ Theory of fustice de J. Rawls una versión modificada?', Teorema I3(I/2): $273^{-83}$.

23. Martinez is the best secondary source for the reception of Rawls in Spain. See Jesus I. Martinez (1986) 'La Recepción de Rawls en España', Anuario de Filosofia del Derecho, pp. 6I I-32. Madrid: Instituto Nacional de Estudios Juridicos. See also Luisa L. Serrano, 'Recepción en Castellano de la obra "Teoria de la Justicia” de John Rawls', Revista Agustiniana 36(1 14): 1087-I I33.

24. F. Vallespín (1985) Nuevas Teorias del Contrato Social: Zohn Rawls, Robert Nozick y Fames Buchanan. Madrid: Alianza; Maria X. Agra (1985) 7. Rawls: El Sentido de Justicia en una Sociedad Democrática. Santiago de Compostela: Monografías de la Universidad de Santiago de Compostela; Martinez, José I. (1985) La Teoria de la fusticia de fohn Rawls. Madrid: Centro de Estudios Constitucionales; M.D. González (1985) Fundamentos, Análisis y Crítica de la Teoria de la fusticia de fohn Rawls. Madrid: Ediciones de la Universidad Complutense.

25. These include C.R. Alba Tercedor, J. Rubio Carracedo, M. Jiménez Redondo, Victoria Camps, E. Fernandez, C.J. Cela Conde, M.A. Rodilla, J. Herrera Flores and J. Mugerza.

26. See, in particular, the many articles published in the journals Isegoria and Revista Internacional de Filosofía Politica. The latter is also an example of the increasingly good relationship between political philosophers in Spain and Latin America.

27. Robert Nozick (1974) Anarchy, State and Utopia, p. I83. N.pl.: Basic Books. 